\title{
The Role of the Catch-22's Narrative Techniques in Reveling the Theme
}

\author{
Yan Jun ${ }^{1, *}$ \\ ${ }^{1}$ Foreign Language Institute, Sichuan University of Science \& Technology, Zigong, Sichuan, China \\ *Correspondence: Foreign Language Institute, Sichuan University of Science \& Technology, Zigong, Sichuan, China. \\ Tel: 86-813-550-5882. E-mail: popococo51@hotmail.com
}

Received: July 18, 2015

Accepted: August 19, 2015 Online Published: September 17, 2015

doi:10.5430/wjel.v5n3p46

URL: http://dx.doi.org/10.5430/wjel.v5n3p46

\begin{abstract}
Catch-22 is Joseph Heller's most famous novel. Being full of flashbacks, repetitions, and conflicting words, the long novel is complex both in language and structure. However, with analysis in light of Wayne C. Booth's theories about the narrator and distance, Gerald Prince's theory about the presuppotition of statement, and Gerard Genette's theory about anachronies, it can be concluded that the narrative techniques applied in the novel, especially, the special narrator and numerous anachronies, play an important role in revealing the main theme, and the superficially chaotic language and structure are proved to be the meticulous arrangement of the author for the disclosure of the main theme of the novel.
\end{abstract}

Keywords: narrative; anachrony; narrator

\section{Introduction}

Catch-22 is Joseph Heller's most famous novel. Through the protagonist, Yossarian's struggle against Catch-22, the novel describes the life and inner world of the American soldiers and officers who are stationed in an Italian Island Pianosa during World War II. Being full of flash backs, repetitions, and conflicting words, the long novel is complex both in language and structure. Since it was first published in 1961, many critiques have been written about it. Some critics, especially some early critics, held the view that Catch-22 lacked the design and structure. However, later critics hold the view that the structure of Catch-22 was meticulously worked out by Heller, and it has some thematic significance.

In the light of Wayne C. Booth's theories about undramatized narrator and the distance, Gerard Genette's theories about focalization and anachronies and Gerald Prince's theory about the presupposition of a statement, this thesis proves that the novel reveals the chaos and absurdity of the world and man's despair in that world through the narrative techniques applied in the novel as well as the story of it.

\section{The Narrator}

In Catch-22, except for some episodes narrated by a few characters in their conversation (such as Odd's description of Orr's reaction when he is shot down into the sea), the story is told by the narrator. So the narrator plays a crucial role in revealing the theme of the novel. It is important to know what kind of narrator he is, and how he tells the story.

\subsection{The Relation between the Narrator and the Story}

In the novel, the narrator has the knowledge of everything, even the inner movements of the characters. Nevertheless, he does not appear as a character in the novel, or address himself as "I" or "we". So, he is out of the story. According to Wayne C. Booth, this kind of narrators is called an undramatized narrator. The undramatized narrator does not appear as a participant or a mere observer in the story or addresses itself as an "I" in the narration. It presents the situations and events with a minimum amount of narratorial mediation. The dramatized narrator is just the reverse.

However, although the narrator in Catch-22 is not in the story, he knows almost everything that has happened or is happening, and has an insider's view of the characters' minds. According to Genette's (1980, p.189) theory about focalization, the novel is of "zero focalization". That means that the narrator has an indeterminate perceptual or conceptual position, so that he knows more than any of the characters. 
It can be argued that, the narrator in Catch-22 is an undramatized narrator with "zero focalization". Although he is out of the story, he knows almost everything in it. Therefore, he has a freedom to choose how to tell the story and plays an important role in revealing the theme of the novel.

\subsection{The Distance between the Narrator and the Characters}

Besides the narrator's relation with the story, the distance between the characters and narrator also determines the latter's role in the narration and his role in revealing the theme.

In Rhetoric of Fiction, Booth (Booth, 1987, p.155) puts forward the concept of distance among the author, the narrator, the other characters, and the reader. According to him, they can "range, in relation to each of the others, from identification to complete opposition, on any axis of value, moral, intellectual, aesthetic, and even physical". The distances "serve to control our sense that we are dealing with an aesthetic object, just as the paper moons and other unrealistic stage effects of some modern drama have had an 'alienation' effect"(Booth, 1987, p156).

Because in Catch-22, all the narration is carried out in the past tense, the narrator is narrating things that have happened in the past. A temporal distance exists between the narrator and the characters. Nevertheless, although in Catch-22, the narrator has the knowledge of all the things and characters in the novel, he does not have a better understanding of them than the characters. He just presents the things as facts or comprehends them in the way of the characters'. For example, in Chapter 34, after the "soldier in white" leaves, another wounded soldier is send to the ward. Instead of explaining that there is another soldier who is so seriously wounded that he has to be completely bandaged, the narrator just presumes, just like what Yossarian would do, that the soldier in white is back, and says, "It was indeed, the same man. He had lost a few inches and added some weigh... He had, in fact, hardly changed at all." (p.374)

The narrator's description of Milo also shows that he is not intellectually superior to the characters. He does not point out that he is a cruel person, who can sacrifice anything in the world for money, except his life. Instead, he just describes what Milo does in a plain tone, without shock or indignation, as if all that Milo does is normal and correct. For instance, as to Milo's contracts with both the American and the German to bomb and defend a bridge at the same time, the narrator just narrates calmly without finding its absurdity or making any criticism.

So, there is no intellectual distance between the narrator and the characters.

With temporal distance between the narrator and the characters, the narrator can tell the story as if telling something that happened in the past. However, with no intellectual distance between them, the narrator could not make sound judgments, and the reader could not rely on the narrator to understand the story. So, the reader has to act like a detective to toil through the story to find out clues and make his own judgment. In this process, the reader can acquire a thorough study and a deep understanding of the novel.

\subsection{The Narrator's Language}

The narrator's language is the medium through which the reader gets to know the story of the novel. It demonstrates what kind of persons the narrator is and heavily affects the understanding of the reader, and contributes to the revealing of the theme. In Catch-22, the narrator's language is similar to the characters'. It is colloquial, full of repetitions and conflicts and shows the narrator's hatred of the war.

For instance, in Chapter 2, to describe the cruelty of the war, the narrator says: "All over the world, boys on every side of the bomb line were laying down their lives for what they had been told was their country" (p.16). In these words, the narrator's hatred of the war is as strong as that of a character who is forced to fight.

Then, in Chapter nine, the narrator describes the basket ball games the officers play as the "games no one gave a damn about winning" (p.90). Here, the narrator appears as one who participates and knows that the game is only a way to relieve the fear of war, and to expend the absurd life in that world, so that no one cares to win.

Besides, in the novel, just like the language of the characters, the language of the narrator is full of conflicts and repetitions, although the causes of them are different.

Generally speaking, there are two causes of conflicts and repetitions in the characters' language. The first cause is the absurd world that the characters live in.

For example, in Clevinger's interrogation, Clevinger has to repeat his own words 'I didn't say you couldn't punish me, sir" (p.79), because he has to answer his superior's question clearly; the corporal has to repeat the colonel's question, because the colonel asks what the question is; the colonel asks the conflicting question: "When didn't you say we couldn't punish you?" (p.79) because he just wants to demonstrate his power and does not care whether there 
is any conflict in his words. So, all the characters in the interrogation do not deliberately make those conflicts and repetitions, and they are not even clearly aware of that. The repetitions and conflicts here are caused by the absurd world they are in, and at the same time become the reflection of it.

The second cause of repetitions and conflicts in the characters' language is the characters themselves. The questions asked by the soldiers and officers in the education section held by Clevinger are good examples. "Who is Spain?" 'Why is Hitler?' 'When is right?"' For another example, when Yossarian asks Orr whether he walks around with anything in his cheeks, Orr says, "I didn't walk around with anything in my cheeks. I walked around with crab apples in my cheeks" (p.24). Those repetitions and conflicts deliberately made by the characters wrest laughter from their disturbing situation, and bring about a kind of humor — black humor.

Black humor is an important literary term of America in 1960's, which refers primarily to a kind of bitter and often outrageous satire. In the introduction of Black Humor Critical Essays, Alan R. Pratt (1993, p. xvii) says that black humor literature is "similar to the literature of existentialism in that it begins with the same assumption - that the world is absurd, but the aim of the black humorist is significantly different from the existentialist", because "rather than stoic resignation or heroic struggle, the black humorist tries to wrest laughter from out cosmic plight" (Pratt, 1993, p. xviii). So, in the black humorist's eye, the existence of man is absurd. Black humor wrests laughter from the absurd world to make the losing graceful. However, in the laughter there is despair.

Therefore, in Catch-22, black humor brought about by repetitions and conflicts in characters' language reflects the characters' despair in the chaotic and absurd world.

Unlike the characters, the narrator is outside of the story. So, the conflicts and repetitions in his language are not caused by the fictional world, but deliberately made by the narrator himself. For example, in the beginning of the novel, the narrator says: "Yossarian was in the hospital with a pain in his liver that fell just short of being jaundice. The doctors were puzzled by the fact that it wasn't quite jaundice. If it became jaundice they could treat it. If it didn't become jaundice and went away they could discharge him. But this just being short of jaundice all the time confused them" (p. 1). In this paragraph, the word "jaundice" is repeated five times, and it is conflicting to say that jaundice is short of. Through the conflict and repetition, the narrator also creates a kind of "black humor".

Although the narrator is outside the story, judging from the time the novel was written and published, it can be assumed that the "present" time when the narrator makes the narration is 1950s or 1960s. So, it can be argued that black humor in the narrator's language shows not only his despair roused by the story in the novel, but also his despair in the world where he makes the narration - the absurd world of the post-war America.

From what have been analyzed above, conclusion can be made that the narrator's language is similar to the language of the characters. It is colloquial and full of repetitions and conflicts, which demonstrate the narrator's despair in the fictional world as well as the real world in 1950s and 1960s.

\subsection{The Identity of the Narrator}

With all the analysis above, a more concrete description of the narrator can be made, and his role in revealing the main theme of the novel can better be explored. Although the narrator is an undramatized narrator with zero focalization, the temporal and intellectual distance between the narrator and the characters, as well as the similarities in the narrator's and characters' language lead to the assumption that the narrator is someone who has the bitter experience similar to the characters'. Taking Heller's experience in World War II into consideration, this assumption can be well justified. Therefore, although the narrator is not a character in the novel, he does not speak as an outsider. He has similar emotions, feelings with the characters, so he tells the story as if he was experiencing in it. His narration lacks the serenity and composure of an outside narrator, and carries the emotions similar to the characters'.

Because of those characteristic, the narrator can stay outside to freely choose his way to tell the story, and at the same time show feelings and emotions similar to the characters' in his narration. In this way, the reader may have a deeper understanding of the characters sufferings and feelings through the narrator's narration as well as the storyline, and the main theme of the novel can be better revealed.

\section{Anachronies}

\subsection{Definition of Anachronies}

In Narrative Discourse, Gerard Genette (1980, p. 36) defined anachronies as "forms of discordance between the two temporal orders of story and narrative". He divides anachronies into two big categories - prolepsis and analepsis. Prolepsis is any "narrative maneuver that consists of narrating or evoking in advance an event that will take place 
later" (Genette, 1980, p.40). Analepsis is any "evocation after the fact of an event that took place earlier than the point in the story where we are at any given moment" (Genette, 1980, p.49). And anlepses are divided into three groups according to their relation to the first narrative. The analepsis, whose entire extent remains external to the extent of the first narrative is called "external" analepsis, while the analepsis whose entire extent is inside the extent of the first narrative is called "internal" analepsis. The analepsis "whose reach goes back to a point earlier and whose extent arrives at a point later than the beginning of the first narrative" (Genette, 1980, p.49) is defined as "mixed analepsis". According to Genette, analepses can also be divided into the complete and partial. The one that "ends on an ellipsis without rejointing the first narrative" is the partial analepsis (Genette, 1980, p. 72), while complete analepses "joints the first narrative without any gap between the two sections of the story" (Genette, 1980, p. 62) .

\subsection{Anachronies in Catch-22}

In Catch-22, there are numerous anachronies. The novel begins in medias res. At the time the novel begins, the number of missions has been raised to 45, and all of the important missions have already been finished: Ferrara, Orivieto, Bologna, and Avignon. That means that most crucial events have already occurred. So, external analepses must be made to introduce the things happening before the novel's beginning point. In the novel, external analepses centralizes from Chapter 2 to Chapter 26. However, neither a single nor the union of some of those analepses can cover the whole period before the beginning point of the first narrative. From Chapter 27 to Chapter 42, except for the repeated retrospect of Snowden's death over Avignon, there are only two analepses. Both are internal and partial. It seems that all the analepses appear randomly and no regulation can be found out, as if the narrator makes and places the analepses casually according to his free will. The reader may easily feel lost in the reading because of those analepses.

What's more, the ambiguous border line between the first narrative and analepses can make the reader more confused. The analepses in chapters from Chapter 1 to Chapter 26 are all partial analepses, and they join with the first narrative or another analepsis so naturally that on the first reading, the reader has trouble to discover where the temporal leaps take place. For example, in Chapter 6, the analepsis about Hungry Joe's nightmares shifts smoothly to the analepsis of the event that Appleby forces Yossarian to take Atabrine tablet. This shift is achieved with a comparative sentence: "It (to cry out in pain every night) makes more sense than Appleby, who was a stickler for regulations and had ordered Kraft to order Yossarian to take his Atabrine tablets on the flight overseas after Yossarian and Appleby had stopped talking to each other" (p. 56). In the main clause of the comparative sentence, the narrator seems to continue the former analepsis, but quietly, and without any foregoing sign in the subordinate clause, the topic is shifted to another anlepsis.

Moreover, the reach and extent of the analepses are not clearly indicated. There are many ellipses in retrospect, and almost all the durations of the ellipses in Catch-22 are not indicated by the narrator. That makes it more difficult for the reader to find out the timeline of the story.

Therefore, because of the numerous anachronies and their ambiguous extent, the reader has a feeling of being trapped in a chaotic and absurd world while reading through the novel, which is similar to the feeling of the characters in the story.

\subsection{The Narrator's Free Flow of Memories—the Reason for Anachronies}

Although the anachronies in the novel are complicated and confusing, they are not randomly made by the author. There must be some explanation for them. With further analysis, it could be seen that those anachronies are made to convey the main theme of the novel.

Although the narrator in Catch-22 is an undramatized narrator and does not appear in the novel as a character or calls himself as "I" or "we", the story is presented through his consciousness, instead of unmediated. Judging from the narrator's language and his distance from the characters, the narrator is someone who has the similar experience with the characters. So, his narration could be seen as his recollection of those similar miserable experiences.

Since everything about the past is clear in the narrator's mind, there is no need to explain everything clearly. That is why quite a few presuppositions are made. Besides, it is not difficult to notice that the repeated events, either the death of Snowden, or Milo's bombing of the squadron, are all the very cruel or absurd ones. The narrator mentions them repeatedly, and only after several analepses, does he fully describe the events and the reader gets to know what actually has happened. Since the narration could be seen as the narrator's recollection of the past, those repetitive analepses of the tragic events could indicate that like everyone who is unwilling to recall unhappy experience in the past, in the deep heart of the narrator, he is unwilling to recall those tragic events. However, those events and persons haunt him all the time, and appear in his memory repetitively. That is why only after several times of recalling, are 
those events completely retrospected.

It can be concluded the narrator's narration could be regarded as his free flow of memories, and those analepses, presuppositions of statements, abrupt and swift shifts in the narration are caused by that. That is also the reason why the structure of the novel seems chaotic.

The narrator's free flow of memories is similar to stream-of-consciousness, but it is different from it.

Stream-of-consciousness is a technique based on the psychological theories of William James, who first used the term in his Principles of Psycology, and James Joyce perfected the technique in Ulysses. According to William James, human's consciousness is a continuous, unstopping flow of thoughts. The process of thought has five characters:

1) Every thought tends to be part of a personal consciousness.

2) Within each personal consciousness thought is always changing.

3) Within each personal consciousness thought is sensibly continuous.

4) It always appears to deal with objects independent of itself.

5) It is interested in some parts of these objects to the exclusion of others, and welcomes or rejects - chooses from among them, in a word-all the while. (James, 1980, p.146)

As a literary method, stream-of-consciousness represents a fictional person's continuous, unstopping flow of thoughts, composed by the blending of the sense-perceptions, feelings, memories, and so on "usually in an unpunctuated or disjointed form of interior monologue"(Baldick, 2000, p. 212). In Catch-22, the author just represents the narrator's recollection of events happened before the beginning of the novel, with numerous, seemingly random analepses. So, Catch-22 is not a work of stream-of-consciousness.

However, the narrator's free flow of memories possesses some characteristics of stream-of-consciousness and can better reveal the main theme of the novel.

For one thing, to record just the narrator's free flow of memories instead of the narrator's stream of consciousness, the author can use the chronological order in the first narrative of the novel, and make the narrator an undramatized and omniscient one; events and periods with little significance can be omitted. For other, in this way, inner movements of the different characters can be vividly presented, and the events happening in the novel can be viewed from the perspectives of different characters, so the cruelty of the war, the absurdity of the chaotic world, and people's despair in the world are revealed from different angles.

At the same time, the novel reveals the cruelty and absurdity of the world and the absence of human's value through the narrator's unwillingness to recall the terrible events in the past. In addition, because there is no intellectual distance between the characters and the narrator, while the anachronies and presuppositions of statements plunge the reader into the chaos of the narrator's mind, the reader cannot rely on the narrator to provide a morally and intellectually correct judgment on the things and persons in the novel. So, as the reader reads through the novel, he experiences the feeling of being in a chaotic and absurd world by himself. In this way, the reader could fully understand what the characters have experienced, and can have a better understanding of the novel. Consequently, the theme of the novel is better revealed.

\section{Conclusion}

Although multiple anachronies in the novel make it seemingly lacking design and structureless, it could be seen that Catch-22 possesses some unique narrative techniques. Firstly, the omniscient outside narrator is not completely outside the story. Judging from his language and the author's writing background, he could be someone who has similar experience with the characters. His narration carries emotions similar to the characters'. With this very special narrator, the author not only can well control the narrative angle by freely going into the characters mind and choosing which part of the story to tell, but also can influence the reader with the emotion carried in the narrator's language.

Besides, those anachronies could be seen as the representation of the narrator's free flow of memories. Thus, as the reader reading through the novel, he not only gets the story, but also experiences the feeling of the narrator which is similar to the characters'. So, the reader could have better understanding of the chaos and absurdity that the characters experience. In this way the reader acquires the theme not only through the story, but also through his reading process.

Consequently, it could be clearly seen, that the narrator is carefully chosen and his way of narration contributes 
greatly to the disclosure of the main theme of the novel.

\section{References}

Baldick, Chris. (2000). Oxford Concise Dictionary of Literary Terms. Shanghai: Shanghai Foreign Language Education Publishing House.

Booth, Wayne. C. (1987). Rhetoric of Fiction. (2nd. edn.). England: Penguin Books Ltd.

Genette, Gerad. (1980). Narrative Discourse. (Jane E. Lewin. Trans.). Oxford: Basil Blackwell.

Heller, Joseph. (1985). Catch-22. New York: Dell Publishing Co., Inc.

James, William. (1980). The Principle of Psychology. Of Robert Maynard Hutchins(Ed). Great Books of the Western World. (23rd. edn.). Chicago: Encyclopedia Britannica, Inc.

Pratt, Alan R. (Ed.). (1993). Introduction. In Black Humor Critical Essays(pp. xvii-xviii). New York: Garland Publishing, Inc.. 